\title{
Pengaruh Pengetahuan Dasar Dan Kompetensi Kewirausahaan Terhadap Motivasi Kewirausahaan Mahasiswa Universitas Tarumanagara
}

\author{
Elvidson Romanto dan Nur Hidayah \\ Program Studi Manajemen, Fakultas Ekonomi dan Bisnis \\ Universitas Tarumanagara, Jakarta \\ Email: elvidson.115160129@stu.untar.ac.id
}

\begin{abstract}
The purpose of this study was to analyze the effect of basic knowledge and entrepreneurial competence on entrepreneurial motivation of the Tarumanagara University Faculty of Economics and Business students. The data used are 2019 data. The population of this study is management students from Tarumanagara University, Faculty of Economics and Business. The 165 students. The sampling technique used purposive sampling. Data collection techniques using a questionnaire distributed online and manually. Data analysis techniques using the SEM PLS method. The results of the analysis concluded that of the two hypotheses there was one hypothesis that was not significant, namely the basic knowledge variable on entrepreneurial motivation of the Tarumanagara University Faculty of Economics and Business students.
\end{abstract}

Keywords: basic knowledge, entrepreneurship competencies, entrepreneurship motivation.

\begin{abstract}
Abstrak: Penelitian ini bertujuan untuk menganalisis pengaruh pengetahuan dasar dan kompetensi kewirausahaan terhadap motivasi kewirausahaan mahasiswa Fakultas Ekonomi dan Bisnis Universitas Tarumanagara. Data yang digunakan adalah data Tahun 2019. Populasi penelitian ini adalah mahasiswa manajemen dari Universitas Tarumanagara Fakultas Ekonomi dan Bisnis. Sampel yang digunakan sebanyak 165 mahasiswa. Teknik pengambilan sampel yang digunakan yaitu purposive sampling. Teknik pengumpulan data menggunakan kuesioner yang disebar secara online dan manual. Teknik analisis data menggunakan metode SEM PLS. Hasil analisis menyimpulkan bahwa dari dua hipotesis terdapat satu hipotesis yang tidak signifikan yaitu variabel pengetahuan dasar terhadap motivasi kewirausahaan mahasiswa Fakultas Ekonomi dan Bisnis Universitas Tarumanagara.
\end{abstract}

Kata kunci: pengetahuan dasar, kompetensi kewirausahaan, motivasi kewirausahaan.

\section{LATAR BELAKANG}

Ekonomi Indonesia merupakan salah satu ekonomi yang berkembang utama dunia yang terbesar di Asia Tenggara dan terbesar ketiga di Asia setelah China dan India, sehingga menjadikan Indonesia sebagai bagian dari anggota G-20. Selama 2 dekade Indonesia terus mengembangkan ekonomi yang difokuskan pada kegiatan industri dan perdagangan untuk meningkatkan kegiatan ekspor keluar negara untuk membangkitkan ekonomi yang di Indonesia dimana pada tahun 1990an dapat menciptakan stabilitas ekonomi, politik dan sosial yang dijadikan sebagai sebuah acuan untuk membangkitkan ekonomi Indonesia yang fokus pada sektor ekspor dan pengolahan sumber daya alam. 
Jumlah penduduk miskin pada Maret 2019 sebanyak 25,14 juta orang atau sebesar 9,41\% menurun sekitar 530 ribu orang terhadap September 2018 dan 800 ribu orang terhadap Maret 2018 dilansir dari bps.go.id. Indonesia mempunyai potensi ekonomi yang tinggi dan mulai mendapatkan perhatian dari dunia internasional, dalam beberapa tahun terakhir ada dukungan kuat dari pemerintah pusat untuk fokus pada ekspor komoditas (mentah), sekaligus meningkatkan peran industri manufaktur dalam perekonomian.

Perkembangan ekonomi Indonesia tidak menjamin adanya perkembangan dalam bidang kewirausahaan dimana keinginan masyarakat Indonesia untuk ikut serta dalam kewirausahaan, masyarakat di Indonesia banyak lebih memilih untuk kerja dibanding melakukan kewirausahaan. Salah satu faktor perkembangan ekonomi Indonesia juga melibatkan para wirausaha untuk meningkatkan ekonomi Indonesia terutama dalam bidang ekspor. Jumlah wirausaha Indonesia saat kini masih kalah jauh dibandingkan dengan Negara tetangga seperti Singapura, Filipina, Malaysia, dan lain-lain. Jumlah pengusaha di Indonesia masih sangat dikit, namun survey yang dilakukan oleh Global Entrepreneurship Monitor (GEM) pada tahun 2013, menunjukkan indonesia sebagai posisi kedua keinginan berwirausaha di ASEAN setelah Filipina.

Kewirausahaan merupakan suatu hal yang penting guna mendorong pertumbuhan ekonomi suatu negara, terutama di negara-negara berkembang seperti di Indonesia. Tingkat pendapatan dan infrastruktur yang relative rendah sehingga Indonesia masih tergolong ke dalam negara berkembang jika dibandingkan dengan negara-negara maju seperti Amerika Serikat, Australia, Jepang dan sebagainya. Jika dilihat dari segi ketersediaan lapanagan kerja, pendapatan perkapita, tingkat pengangguran di Indonesia juga relatif lebih tinggi jika dibandingkan dengan negara-negara maju. Ada beberapa alasan kewirausahaan dapat mendorong perekonomian di suatu Negara, dengan adanya wirausaha yang kreatif dan inovatif, kebutuhan yang dibutuhkan masyarakat akan dapat dipenuhi sendiri tanpa harus impor sehingga impor dapat dijaga yang dapat mengakibatkan perkembangan ekonomi Indonesia. Hal penting lainnya adalah dengan adanya wirausaha yang kreatif dan inovatif ini, akan membantu mengurangi jumlah pengangguran di suatu negara sehingga angka kemiskinan di Indonesia dapat berkurang dan juga menyediakan lapangan kerja.

Neck dan Greene (2011) menjelaskan kewirausahaan adalah peluang baru yang diciptakan dan diimplementasi dalam suatu lingkungan dengan kompleksitas yang tinggi. Kewirausahaan dianggap sebagai salah satu indikator yang dapat dijadikan sebuah faktor untuk membangun ekonomi Indonesia sehingga kewirausahaan sangat penting dalam peran membangun ekonomi Indonesia seperti ekspor, produksi dan lain-lain. Hasil dari survei yang dilakukan di sembilan negara Asia Pasifik yaitu Hong Kong, Malaysia, Filipina, Indonesia, Singapura, Thailand, Korea Selatan, Jepang dan Australia, mengungkapkan bahwa terdapat 7 dari 10 responden atau 71\% responden Asia Pasifik berkeinginan untuk membuka dan memiliki bisnis sendiri. Keinginan untuk menjadi wirausaha sebesar 96\% pada responden Indonesia menjadi terkuat dibanding negara lain di Asia Pasifik mengaku mempunyai cita-cita untuk memulai usaha sendiri yang sedang kapan untuk memulainnya dan tanda-tanda positif yang pas untuk memulai dilansir dari Herbalife Nutrition Survey (2019). Sebanyak 52\% responden Indonesia yang buka usaha, lebih berkeinginan untuk menyalurkan passion dan sekalian menambah pendapatan, sehingga dari survei diatas kita dapat melihat keinginan kewirausahaan masyarakat indonesia, motivasi kewirausahaan yang tinggi tersebut tentunya terdapat dorongan yang menjadi penyebab keinginan kewirausahaan yang tinggi, sehingga harus melakukan pengembangan keinginan berkewirausahaan kepada masyarakat seperti beberapa negara berupaya meningkatkan 
kewirausahaan dengan memperkenalkan berbagai program dalam pendidikan di universitas. Tindakan yang dilakukan oleh pemerintah itu sangat bermanfaat untuk mendukung motivasi kewirausahaan, institusi pendidikan tinggi memberi perhatian khusus pada kewirausahaan karena itu memungkinkan mereka untuk menyatakan diri sebagai orang yang berkontribusi pada ekonomi. Laukkanen (2000) mengatakan bahwa respon strategis dari pendidikan kewirausahaan yang dapat berkontribusi pada peningkatan aktivitas kewirausahaan. Rasmussen dan Sorheim (2006) menjelaskan adanya peran penting dari universitas dalam meningkakan kompetensi kewirausahaan mahasiswa mereka, memotivasi mereka untuk melakukan kegiatan kewirausahaan sebagai tujuan hidup mereka. Sardiman (2006) mengatakan motivasi merupakan energi dalam diri seseorang yang berubah ditandai dengan munculnya perasaan keinginan dengan tanggapan terhadap adanya tujuan yang ingin diraih. Aspek yang dibutuhkan untuk meningkatkan rasa keinginan untuk berwirausaha perlu adanya dorongan dalam diri orang untuk melakukan kewirausahaan. Motivasi dikaitkan sebagai keinginan mencapai sebuah tujuan dari dalam diri yang tinggi dan untuk meningkatkan motivasi masyarakat Indonesia dalam berwirausaha dibutuhkan pengembangan motivasi kewirausahaan yang dapat dikembangkan. Beberapa cara yang mungkin dapat memunculkan rasa motivasi yaitu pengetahuan dasar dan kompetensi kewirausahaan.

Pengetahuan dasar kewirausahaan berperan meningkatkan kompetensi kewirausahaan seperti mengoptimalkan pengunaan sumber daya, efisiensi biaya dan lainlain dengan membangun pola pikir peserta didik yang maju. Peranan dari universitas yaitu memberikan dorongan motivasi, mengajarkan mengidentifikasi peluang bisnis, mengelola usaha dan yang lain untuk meningkatkan motivasi mahasiswa. Pentingnya pengetahuan dasar dalam sebuah usaha dilihat dengan masyarakat yang mengerti dasar-dasar pengetahuan yang dapat dijadikan sebagai bagian dari perkembangan motivasi kewirausahaan sehingga pengetahuan dasar dapat dijadikan sebagai variabel yang dapat diteliti.

Kompetensi kewirausahan yaitu kesiapan seseorang menjadi wirausaha, seperti memiliki mental yang kuat, sikap kepribadian wirausaha, kepekaan terhadap lingkungan, memotivasi orang, berani ambil resiko, mendapatkan ide-ide baru, berkomitmen pada sasaran bisnis jangka panjang, mengembangkan hubungan saling percaya dengan orang lain, merencanakan operasi bisnis, , berinteraksi dengan orang lain secara efektif, melakukan kerjasama untuk menyelesaikan pekerjaan, menjadikan masalaha sebagai peluang bisnis yang menguntungkan, menerapkan ide dalam konteks alternatif, memahami barang atau jasa yang diinginkan pelanggan melalui perkataan dan lain-lain. yang siap untuk berwirausaha dalam menghadapi permasalahan dan kemampuan orang tersebut dalam berwirausaha. Daryanto (2012) mengatakan mahasiswa adalah sumber daya manusia yang diharapkan menjadi wirausaha yang kompeten dan kaum intelektual harus berani untuk mengembangkan potensi diri dan universitas adalah sebuah tempat untuk menemukan, mengembangkan dan mengimplementasikan ide dan kreatifitas sehingga dapat mendapatkan lulusan sarjana untuk menjadi wirausahawan baru yang memiliki daya saing dan kompetensi kewirausahaan yang tinggi. Oleh karena itu, Universitas Tarumanagara khususnya Fakultas Ekonomi dan Bisnis yang mempunyai visi menjadi pencetak entrepreneur dan profesional yang berintegritas di Asia Tenggara yang menghasilkan lulusan yang kompeten, berintegritas, profesional dan berjiwa entrepreneur perlu meningkatkan motivasi mahasiswa untuk berwirausaha. 
Pengetahuan dasar penting dalam meningkatkan motivasi kewirausahaan dimana pengetahuan dasar seperti dasar-dasar akuntansi, pemasaran, keuangan, strategi perusahaan, sumber daya manusia, hukum bisnis, pengelolaan dan keuangan, sehingga mahasiswa mengerti dasar-dasar dari pengetahuan tersebut yang berguna untuk memulai dan menjalani usaha, dasar dari pengetahuan yang mengembangkan mahasiswa memiliki pemahaman terhadap pengetahuan dasar yang dapat mengembangkan motivasi kewirausahaan.

Agus Wibowo (2011) mengatakan pendidikan kewirausahaan merupakan upaya meningkatkan jiwa dan mental kewirausahaan baik melalui institusi pendidikan maupun institusi lain seperti lembaga pelatihan dan sebagainya. Pendidikan kewirausahaan memberikan kepada mahasisawa kesempatan mengembangkan kemampuan kewirausahaannya seperti cara memulai dan mengoperasikan bisnis baru agar berhasil dan menguntungkan, pentingnya pelajaran tentang kewirausahaan dilakukan sejak dini dimulai dari level pendidikan yang terendah untuk membentuk motivasi berwirausaha karena harus diajarkan dari dini untuk bisa mendapatkan kematangan dalam berwirausaha. Pentingnya pendidikan tersebut maka universitas bisa menciptakan hubungan dengan melibatkan masyarakat yang ada di sekitar lingkungan kampus. Selain itu, memberikan kesempatan kepada mahasiswa untuk menjalani usaha secara mandiri dengan sistem magang atau praktek langsung yang terstruktur dari universitas. Proses ini bisa dilakukan melalui sistem perkuliahan namun juga bisa lewat praktek langsung dalam waktu tertentu yang kemudian mendapatkan penilaian, pentingnya pendidikan dasar kewirausahaan untuk membangkitkan keinginan untuk memulai dan menjalani usaha yang merupakan dasar dari kewirausahaan tersebut sehingga mengembangkan komptensi kewirausahaan. Pengetahuan dasar kewirausahaan yang dimaksud berupa pelajaran, penerangan dan lain-lain, diberikan agar terciptanya motivasi dari dalam diri untuk memiliki semangat kewirausahaan, pengetahuan yang didapatkan oleh mahasiswa itulah yang akan membangkitkan keinginan kewirausahaan dari dalam diri sehingga mengetahui dasar-dasar dari kewirausahaan, pandai membaca peluang usaha, melihat masalah sebagai sebuah pelajaran yang berharga untuk nantinya.

\section{KAJIAN TEORI}

Pengetahuan Dasar. Kamus Besar Bahasa Indonesia (2002) terdapat pengetahuan dasar adalah segala sesuatu yang diketahui berkenaan dengan hal mata pelajaran.

Pudjawidjana (2010) mengatakan pengetahuan dasar adalah rangsangan dari alam sekitar melalui sentuhan dengan objek tertentu melalui indera sehingga menghasilkan sebuah reaksi dari manusia dan objek tertentu yang telah diindera oleh manusia akan menghasilkan sebuah hasil yaitu pengetahuan.

Gordon (1994) pengetahuan dasar adalah suatu fakta prosedur yang akan meningkatkan kinerja saat dilakukan sesuai dengan struktur organisasi.

Beberapa pengertian pengetahuan dasar tersebut dapat disimpulkan bahwa pengetahuan dasar merupakan dasar-dasar dari suatu teori dalam pengajaran tersebut yang telah didapatkan melalui indera yang sudah diuji kefaktaanya dan dasar dari suatu pelajaran yang mempelajari dasar-dasar subjek tersebut yang disajikan. 
Kompetensi Kewirausahaan. Fithri dan Amanda (2012) menjelaskan kompetensi kewirausahaan diartikan sebagai tingkat kinerja kewirausahaan yang secara langsung dipengaruh oleh keterampilan, pengetahuan dan kemampuan individu.

Erikson (2002) mengatakan kompetensi kewirausahaan adalah kemampuan menemukan dan bertindak sesuai ide serta mengubah ide menjadi hasil melalui pemanfaatan sumber daya diperlukan.

Bird (1995) mengatakan kompetensi kewirausahaan adalah kemampuan yang dimiliki seseorang untuk menjaga ketegangan duniawi, hubungan kewirausahaan, rencana strategis, kemampuan untuk menciptakan dan menjalani hubungan baik dengan orang.

Pengertian tersebut dapat diartikan bahwa kompetensi kewirausahaan adalah kemampuan yang dimiliki oleh seseorang seperti keterampilan, ilmu pengetahuan, dan kualitas diri untuk mendapatkan dorongan untuk menjalankan kegiatannya yaitu wirausaha yang memiliki semangat tinggi untuk sukses.

Motivasi Kewirausahaan. Motivasi adalah suatu faktor yang mendorong seseorang untuk melakukan sesuatu, sehingga motivasi dapat diartikan pendorong perilaku seseorang.

Wikanso (2013) artian kewirausahaan motivasi dapat diartikan sebagai dalam diri seorang wirausaha adanya keseluruhan daya motivasi yang menjadi penggerak melakukan kegiatan wirausaha yang menjamin kegiatan wirausaha secara langsung dan memberi arahan terhadap kegiatan wirausaha tersebut sehingga tujuan yang diinginkan akan tercapai.

Motivasi berwirausaha adalah adanya dorongan dari dalam diri orang untuk memahami kemampuan wirausaha yang dimiliki dengan berfikir secara inovatif dan kreatif untuk mengubah suatu barang menjadi bernilai untuk kepentingan kebutuhan dan memenuhi kebutuhan dengan menciptakan produk baru.

Suryaman (2006) menyatakan keinginan berwirausaha adalah keinginan untuk memenuhi kebutuhan hidup dengan memberanikan diri dalam memanfaatkan kemampuannya serta permasalahan yang dipecahkan, mengembangkan usaha atau kekuatan yang ada dalam diri seseorang untuk menciptakan usaha baru, jadi untuk meningkatkan motivasi kewirausahaan guna melihat pengetahuan dasar dan kompetensi kewirausahaan.

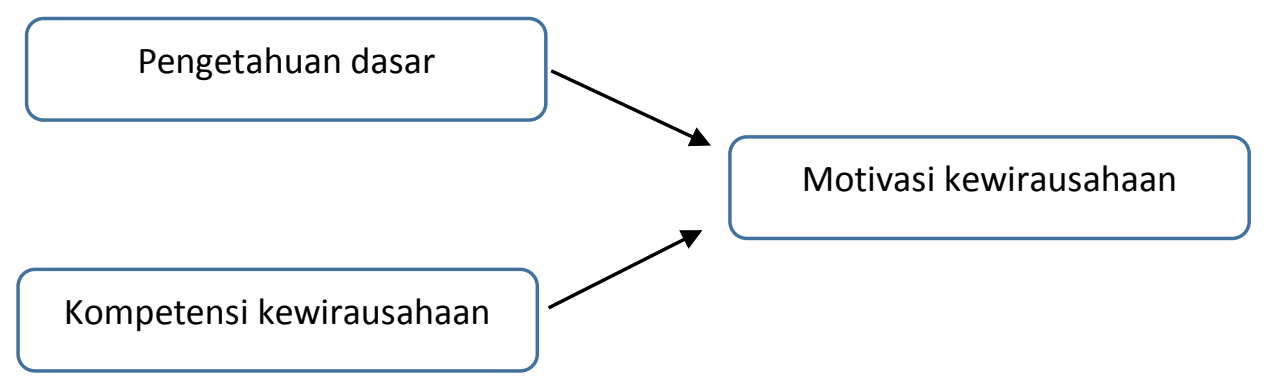

Gambar 2.1 Model Penelitian

$\mathbf{H}_{1}$ : Terdapat pengaruh positif pengetahuan dasar terhadap motivasi kewirausahaan mahasiswa Fakultas Ekonomi dan Bisnis Universitas Tarumanagara.

$\mathbf{H}_{2}$ :Terdapat pengaruh positif kompetensi kewirausahaan terhadap motivasi kewirausahaan mahasiswa Fakultas Ekonomi dan Bisnis Universitas Tarumanagara. 


\section{METODOLOGI}

Penelitian ini menggunakan desain penelitian konklusif yang bersifat deskriptif dimana terdapat dalam teori-teori sebelumnya yang ada untuk menghasilkan sebuah penelitian. Penelitian ini menggunakan SmartPLS sebagai dasar pengujian dengan menggunakan data yang sudah didapatkan dari responden berupa pengisian kuesioner yang disebar secara online dan manual. Populasi dalam penelitian ini adalah mahasiswa berjurusan manajemen di Fakultas Ekonomi dan Bisnis Universitas Tarumanagara. Peneliti menggunakan purposive sampling dimana responden tidak dipilih secara acak diamana mahasiswa dengan jurusan manajemen sebagai responden dari penelitian ini. Instrumen yang digunakan dalam penelitian ini ialah kuisioner dengan sebanyak 165 responden untuk dijadikan sebagai penelitian.

Uji yang digunakan dalam penelitian ini yaitu uji validitas dan relalibilitas. Analisis data menggunakan uji R Square (R2), Cross-Validated Redudancy (Q2), Path Coefficients, Effect Size ( $\left.f^{2}\right)$, Goodness of Fit (GoF) dan pengujian Hipotesis.

\section{Hasil Analisis Data \\ Hasil Uji Validitas.}

Tabel 3.4. Hasil Analisis Average Variance Extracted (AVE)

\begin{tabular}{|c|c|}
\hline Variabel & Average Variance Extracted $(\boldsymbol{A V E})$ \\
\hline Kompetensi Kewirausahaan & 0.599 \\
\hline Motivasi Kewirausahaan & 0.518 \\
\hline Pengetahuan Dasar & 0.657 \\
\hline
\end{tabular}


Romanto dan Hidayah: Pengaruh Pengetahuan Dasar Dan Kompetensi Kewirausahaan...

Tabel 3.5. Hasil Analisis Outer Loadings

\begin{tabular}{|l|c|c|c|}
\hline & $\begin{array}{c}\text { Kompetensi } \\
\text { Kewirausahaan (X2) }\end{array}$ & $\begin{array}{c}\text { Motivasi Kewirausahaan } \\
(Y)\end{array}$ & $\begin{array}{c}\text { Pengetahuan Dasar } \\
\text { X1) }\end{array}$ \\
\hline KK01 & 0.734 & & \\
\hline KK02 & 0.740 & & \\
\hline KK03 & 0.769 & & \\
\hline KK04 & 0.798 & & \\
\hline KK05 & 0.771 & & \\
\hline KK06 & 0.812 & & \\
\hline KK07 & 0.784 & & \\
\hline KK08 & 0.725 & & \\
\hline KK09 & 0.754 & & \\
\hline KK10 & 0.810 & & \\
\hline KK11 & 0.806 & 0.681 & \\
\hline KK12 & 0.779 & 0.565 & \\
\hline MK01 & & 0.569 & \\
\hline MK02 & & 0.679 & \\
\hline MK03 & & 0.726 & \\
\hline MK04 & & 0.755 & \\
\hline MK05 & & 0.726 & \\
\hline MK06 & & 0.810 & \\
\hline MK07 & & 0.707 & \\
\hline MK08 & & 0.796 & \\
\hline MK09 & & 0.816 & \\
\hline MK10 & & & \\
\hline MK11 & & & \\
\hline MK12 & & & \\
\hline MK13 & & & \\
\hline MK14 & & & \\
\hline PD01 & & & \\
\hline PD02 & & & \\
\hline PD03 & & & \\
\hline PD04 & & & \\
\hline PD05 & & & \\
\hline PD06 & & & \\
\hline & & & \\
\hline
\end{tabular}

Berdasarkan hasil AVE pada tabel 3.4 dapat diketahui bahwa semua variabel dalam penelitian ini valid karena nilai AVE yang lebih besar dari 0,5 dan Outer Loadings lebih besar dari 0,5 .

\section{Hasil Uji Reliabilitas.}

Tabel 3.7. Hasil Analisis Reliabilitas

\begin{tabular}{|l|c|c|}
\hline \multicolumn{1}{|c|}{ Variabel } & Cronbach's Alpha & Composite Reliability \\
\hline Kompetensi Kewirausahaan & 0.939 & 0.947 \\
\hline Motivasi Kewirausahaan & 0.927 & 0.937 \\
\hline
\end{tabular}




\section{\begin{tabular}{|l|r|r}
\hline Pengetahuan Dasar & 0.896 & 0.920
\end{tabular}}

Nilai Cronbach's alpha dan Composite reliability lebih besar dari 0,70 sehingga disimpulkan seluruh variabel dalam penelitian ini reliabel yang ditunjukkan pada Tabel 3.7 .

Coefficient of Determination atau $\mathbf{R}$ Square $\left(\mathbf{R}^{2}\right)$.

Tabel 4.7. Hasil Analisis $\mathbf{R}^{2}$

\begin{tabular}{|c|c|}
\hline Variabel & R Square \\
\hline Motivasi Kewirausahaan & 0.514 \\
\hline
\end{tabular}

Berdasarkan hasil analisis $\mathrm{R}^{2}$ pada Tabel 4.7, maka variabel motivasi kewirausahaan memiliki $\mathrm{R}^{2}$ sebesar 0,514 . Artinya, sebesar $51,4 \%$ variabel motivasi kewirausahaan dapat dijelaskan oleh variabel pengetahuan dasar dan kompetensi kewirausahaan.

Cross-Validated Redudancy $\left(\mathbf{Q}^{2}\right)$.

Tabel 4.8. Hasil Analisis $\mathbf{Q}^{2}$

\begin{tabular}{|l|r|r|r|}
\hline & \multicolumn{1}{|l|}{ SSO } & \multicolumn{1}{l|}{ SSE } & $\mathrm{Q}^{2}(=1-\mathrm{SSE} / \mathrm{SSO})$ \\
\hline Kompetensi Kewirausahaan & 1.980 .000 & 1.980 .000 & 0.235 \\
\hline Motivasi Kewirausahaan & 2.310 .000 & 1.766 .828 & \\
\hline Pengetahuan Dasar & 990.000 & 990.000 & \\
\hline
\end{tabular}

Berdasarkan hasil analisis $\mathrm{Q}^{2}$ pada Tabel 4.8 maka dapat diperoleh nilai $\mathrm{Q}^{2}$ sebesar 0,235 pada motivasi kewirausahaan. Dengan demikian, endogenous construct dapat dinyatakan relevan, dapat memprediksi model penelitian karena mempunyai nilai $\mathrm{Q}^{2}$ lebih besar dari 0 .

Path Coefficients.

Tabel 4.9. Hasil Bootstrapping

\begin{tabular}{|l|c|c|c|}
\hline \multicolumn{1}{|c|}{ Variabel } & Original Sample & t-statistics & p-values \\
\hline $\begin{array}{l}\text { Kompetensi Kewirausahaan } \rightarrow \\
\text { Motivasi Kewirausahaan }\end{array}$ & 0.680 & 5.516 & 0.000 \\
\hline $\begin{array}{l}\text { Pengetahuan Dasar } \rightarrow \text { Motivasi } \\
\text { Kewirausahaan }\end{array}$ & 0.045 & 0.343 & 0.366 \\
\hline
\end{tabular}

Berdasarkan hasil yang ditampilkan diatas, maka dapat diperoleh persamaan variabel yaitu:

$$
\mathrm{MK}=0,680 \mathrm{KK}+0,045 \mathrm{PD}
$$

Persamaan tersebut memperlihatkan adanya pengaruh variabel kompetensi kewirausahaan terhadap motivasi kewirausahaan yang berpengaruh positif sebesar 0,680 dan variabel pengetahuan dasar mempunyai pengaruh positif sebesar 0,045 terhadap motivasi kewirausahaan. Kesimpulan dari persamaan diatas yaitu pengaruh kompetensi kewirausahaan terhadap motivasi kewirausahaan lebih besar dari pada pengaruh pengetahuan dasar terhadap motivasi kewirausahaan. 
Effect Size $\left(\mathbf{f}^{2}\right)$.

Tabel 4.10. Hasil Effect Size

\begin{tabular}{|c|c|c|c|}
\hline & $\begin{array}{l}\text { Kompetensi } \\
\text { Kewirausahaan }\end{array}$ & $\begin{array}{l}\text { Motivasi } \\
\text { Kewirausahaan }\end{array}$ & Pengetahuan Dasar \\
\hline $\begin{array}{l}\text { Kompetensi } \\
\text { Kewirausahaan }\end{array}$ & & 0.298 & \\
\hline $\begin{array}{l}\text { Motivasi } \\
\text { Kewirausahaan }\end{array}$ & & & \\
\hline Pengetahuan Dasar & & 0.001 & \\
\hline
\end{tabular}

Berdasarkan hasil effect size pada Tabel 4.10 diketahui variabel motivasi kewirausahaan, efek yang dimiliki oleh kompetensi kewirausahaan sebesar 0,298 menunjukkan efek sedang, sedangkan efek yang dimiliki oleh pengetahuan dasar sebesar 0,001 yang menunjukkan efek yang kecil atau tidak adanya efek pada motivasi kewirausahaan dalam penelitian ini.

Goodness of Fit (GoF).

$\mathrm{GoF}=\sqrt{\overline{A V E} \times \overline{R^{2}}}$

$\mathrm{GoF}=\sqrt{0,591 \times 0,514}$

$\mathrm{GoF}=\sqrt{0,304}$

$\mathrm{GoF}=0,551$

Berdasarkan hasil perhitungan diatas nilai goodness of fit (GoF) sebesar 0,551. Nilai tersebut memiliki ukuran besar yang artinya variabel independen dapat memprediksi model secara keseluruhan dengan baik.

Pengujian Hipotesis.

Tabel 4.11. Hasil Pengujian Hipotesis

\begin{tabular}{|l|c|c|c|}
\hline \multicolumn{1}{|c|}{ Variabel } & t-statistics & $p$-values & Hasil \\
\hline $\begin{array}{l}\text { Kompetensi Kewirausahaan } \rightarrow \text { Motivasi } \\
\text { Kewirausahaan }\end{array}$ & 5.742 & 0.000 & Tidak ditolak \\
\hline $\begin{array}{l}\text { Pengetahuan Dasar } \rightarrow \text { Motivasi } \\
\text { Kewirausahaan }\end{array}$ & 0.362 & 0.359 & Ditolak \\
\hline
\end{tabular}

\section{DISKUSI}

Berdasarkan hasil uji data dari validitas, reliabilitas, R Square, Cross-Validated Redudancy $\left(\mathrm{Q}^{2}\right)$, path coefficient, Goodness of Fit $(\mathrm{GoF})$, effect size $\left(\mathrm{f}^{2}\right)$ dan pengujian hipotesis dapat disimpulkan hipotesis pertama ditolak dan hipotesis kedua tidak ditolak. Hasil penelitian menunjukkan bahwa kompetensi kewirausahaan memiliki pengaruh yang positif terhadap motivasi kewirausahaan mahasiswa Fakultas Ekonomi dan Bisnis Universitas Tarumanagara maka mahasiswa yang memiliki kompetensi kewirausahaan 
tinggi akan meningkatkan motivasi mahasiswa untuk berwirausaha, hasil tersebut sejalan dengan penelitian yang dilakukan oleh (Minoo, Paulo, dan Maria, 2016) yang berjudul "Predicting entrepreneurial motivation among university students". Penelitian ini dilakukan di Universitas Minho Portugal dimana memiliki tujuan untuk mengetahui pendorong utama motivasi kewirausahaan kalangan mahasiswa. Hasil hipotesis pada variabel pengetahuan dasar yang didapatkan sebesar $\beta=-0,13$ dan $\mathrm{P}>0,01$ yang berarti tidak signifikan dimana tidak ada bukti yang kuat bahwa pengetahuan dasar memiliki efek positif pada motivasi kewirausahaan. Hal ini memperkuat tidak adanya pengaruh signifikan antara pengetahuan dasar terhadap motivasi kewirausahaan pada mahasiswa Fakultas Ekonomi dan Bisnis Universitas Tarumanagara sedangkan pengetahuan dasar tidak memiliki pengaruh yang positif terhadap motivasi kewirausahaan yang artinya pemahaman pengetahuan dasar yang tinggi tidak memotivasi mahasiswa dalam berwirausaha, hasil tersebut sejalan dengan penelitian yang dilakukan oleh (Minoo, Paulo, dan Maria, 2016) yang berjudul "Predicting entrepreneurial motivation among university students". Penelitian memiliki tujuan untuk mengetahui pendorong utama kewirausahaan yang dilakukan di Universitas Minho Portugal pada kalangan mahasiswa. Hasil hipotesis pada variabel pengetahuan dasar yang didapatkan sebesar $\beta=0,429$ dan $\mathrm{P}<0,01$ berarti terdapat pengaruh signifikan bahwa kompetensi kewirausahaan memiliki efek positif pada motivasi kewirausahaan. Hal ini memperkuat adanya pengaruh signifikan antara kompetensi kewirausahaan terhadap motivasi kewirausahaan pada mahasiswa Fakultas Ekonomi dan Bisnis Universitas Tarumanagara..

Maka Universitas Tarumanagara Fakultas Ekonomi dan Bisnis harus meningkatkan kompetensi kewirausahaan mahasiswa untuk memotivasi mahasiswa untuk berwirausaha.

\section{PENUTUP}

Hasil penelitian menunjukkan bahwa kompetensi kewirausahaan memiliki pengaruh yang positif terhadap motivasi kewirausahaan mahasiswa Fakultas Ekonomi dan Bisnis Universitas Tarumanagara sedangkan pengetahuan dasar tidak memiliki pengaruh yang positif terhadap motivasi kewirausahaan.

Saran kepada peneliti selanjutnya agar memakai variabel pengetahuan dasar tersebut dengan indikator yang berbeda dengan penelitian ini guna melihat hasilnya dan mencakup faktor-faktor yang lebih luas dan menambahkan variabel lainnya yang memengaruhi motivasi kewirausahaan.

\section{DAFTAR PUSTAKA}

Agus, W. (2011). Pendidikan Kewirausahaan (Konsep dan Strategi). Yogyakarta: Pustaka Pelajar.

Badan Pusat Statistik. (2019). Profil kemiskinan di Indonesia Maret 2019 (Retrieved from: www.bps.go.id)

Bird, B. (1995). Towards a theory of entrepreeurial competency in Katz, J. \& Brockhaus, R. H. (Eds.), Advances in entrepreneurship, firm emergence and growth, 21(2), 5172.

Daryanto. (2012). Model Pembelajaran Inovatif. Yogyakarta: Gava Media.

Erikson, T. (2002). Entrepreneurial capital: the emerging venture's most important asset and competitive advantage. Journal of Business Venturing, 17(2), 275-290. 
Fithri, P. \& Amanda, F. S. (2012). Analisis Kompetensi Kewirausahaan Industri Kecil Suku Cadang di Kota Padang. Optimasi Sistem Industri, 11(2), 280.

Gordon, B. (1994). Management System Information. Jakarta: Midas Surya Grafindo.

Herbalife Nutrition Survey. (2019). The Asia Pacific Entrepreneurship Insights Survey 2019. Asia: Herbalife Nutrition.

Laukkanen, M. (2000). Exploring alternative approaches in high-level entrepreneurship education: creating micromechanisms for endogenous regional growth. Entrepreneurship and Regional Development, 12(1), 25-47.

Minoo, F., Paulo, G., \& Maria, S. (2016). Predicting entrepreneurial motivation among university students. Journal of Entrepreneur, 58(7), 861-881.

Neck, H. \& Greene, P. (2011). Entrepreneurship education: known worlds and new frontiers. Journal of Small Business Management, 49(1), 55-70.

Pudjawidjana. (2010). Cara Penerapan Proses Pembelajaran Yang Baik. Jakarta: PT Raja Grafindo.

Rasmussen, E. \& Sorheim, R. (2006). Action-based entrepreneurship education. Technovation, 26 (2), 185-194.

Sardiman, A. M. (2006). Interaksi dan Motivasi Belajar-Mengajar. Jakarta: PT Raja Grafindo Persada.

Suryaman. (2006). Minat Berwirausaha Pada Mahasiswa Pendidikan Teknik Elektro Fakultas Teknik Universitas Negeri. Semarang: Laporan Penelitian UNES.

Tim Penyusun Kamus Pusat. (2002). Kamus Besar Bahasa Indonesia. Jakarta: Balai Pustaka.

Wikanso. (2013). Pengaruh Pendidikan Kewirausahaan Terhadap Motivasi Berwirausaha Mahasiswa STKIP PGRI Ngawi. Jurnal Ilmiah STKIP PGRI Ngawi. 11(1), 4-5. 